\title{
RANCANG BANGUN CONVEYOR MESIN PLANER KAYU DENGAN SISTEM PENGGERAK MOTOR STEPPER
}

\author{
Sigit Nugroho Utomo \\ Fakultas Teknik, Program Studi Teknik Mesin \\ Universitas Muria Kudus \\ Email:201454093@std.umk.ac.id \\ Rochmad Winarso \\ Fakultas Teknik, Program Studi Teknik Mesin \\ Universitas Muria Kudus \\ Email: rochmad.winarso@umk.ac.id \\ Qomaruddin \\ Fakultas Teknik, Program Studi Teknik Mesin \\ Universitas Muria Kudus \\ Email: qomaruddin@umk.ac.id
}

\begin{abstract}
ABSTRAK
Planer kayu merupakan mesin serut kayu yang dapat membersihkan permukaan kayu agar menjadi lebih rata atau lebih halus. Mesin planer biasanya digunakan dalam skala kecil maupun juga skala yang lebih besar atau skala industri. Dalam pengembangan mesin planer yang telah dibuat sebelumnya diperlukan penambahan conveyor yang digunakan sebagai pembawa bahan baku yaitu kayu sehingga lebih efisien dalam proses produksinya. Metode yang digunakan meliputi studi literatur, studi lapangan, proses perancangan serta proses manufaktur. Pada hasil penelitian telah dibuat, conveyor pada mesin planer kayu dengan sistem penggerak motor stepper didapatkan hasil perbedaan kecepatan conveyor tanpa beban dan dengan beban sebesar 0,025 $0,014 \mathrm{~m} /$ detik.
\end{abstract}

Kata kunci: mesin planer, conveyor, putaran, kecepatan

\section{ABSTRACT}

Wood planer machines is wood shavings machines are surface cleaning machines to be more flat or finer. Planer machines are usually used in small scale or larger scale or industrial scale. In the development of planer machines that have been made before, a carrier is needed which is used by wood transporters so that it is more efficient in the productions process. The method used uses literature studies, field studies, design processes and manufacturing processes. In the results of the research that has been made, the conveyor on a wood planer machine with a motor drive system produces the results of a no-load conveyor speed and a load of 0,025-0,014 $m / s$

Keywords: planer machine, conveyor, rotation, speed

\section{PENDAHULUAN}

Seiring berkembangnya zaman, kebutuhan akan teknologi juga menjadi semakin kompleks. Maka dari itu pemanfaatan teknologi juga semakin tinggi terutama kebutuhan akan mesin sehingga pembuatan mesin ini menjadi jawaban dari kebutuhan tersebut. Karya yang dapat dimuat adalah yang mengkaji masalah yang berhubungan dengan teknologi dibidang teknik mesin [1].

Kerajinan kayu merupakan salah satu kebutuhan manusia yang penting. Hasil karya kerajinan dari bahan baku kayu adalah meja, kursi, almari, jendela, pintu dan furniture. Permintaan akan mebel/furniture pada saat ini cukup baik untuk individu maupun ekspor. Kebutuhan dan permintaan akan produk meubel 
semakin meningkat, tetapi kurang diimbangi dengan tingkat penyelesaian order meubelnya dikarenakan SDM dan tekhnologi yang kurang memadai [2].

Mesin serut otomatis merupakan alat yang di gunakan sebagai penghalus kayu berkapasitas tinggi. Mesin serut kayu ini dalam pengerjaan penghalusan permukaan benda kerja dua sisi sekaligus secara otomatis. Dan juga mesin ini dapat membentuk profil bagian sudut benda kerja [3].

Bentuk naik turunnya meja dan conveyor telah disesuaikan dengan sistem kontrol otomatis sehingga naik turun meja dan laju conveyor telah disesuaikan menjadikan mesin ini lebih efisien dalam ukuran dan hasil dari pemakanan kayu yang dihasilkan. Dengan mesin ini memungkinkan untuk memaksimalkan kerja mesin ini. Sehingga, dalam perkembangannya mesin ini dapat memudahkan pengrajin kayu dalam skala sedang.

Mesin planer kayu sistem otomatis dapat meningkatkan efektifitas hasil yang dibuat. Perancangan mesin planer kayu dilakukan dengan tahapan melakukan identifikasi mesin yang sudah ada sehingga dapat diketahui mesin planer apa yang dibutuhkan dan dengan kapasitas berapa. Setelah itu melakukan perancangan dengan memodifikasi meja, sistem kontrol dan menambahkan conveyor pada meja , kemudian membuat mesin sesuai dengan gambar yang telah direncanakan, lalu yang terakhir adalah menganalisa kinerja mesin [4]. Tujuan penulisan ini adalah melakukan rancang bangun conveyor pada mesin planner kayu sistem kontrol otomatis dengan menggunakan motor stepper.

Conveyor merupakan suatu mesin pemindah bahan yang umumnya dipakai dalam industri perakitan maupun industri proses untuk mengangkut bahan produksi setengah jadi maupun hasil produksi dari satu bagian ke bagian yang lain. Ada dua jenis material yang dapat dipindahkan, yaitu muatan curah (bulk load) dan muatan satuan (unit load)[5]. Analisa kekuatan pada bentuk screw konveyor dapat dilakukan dengan metode elemen hingga [6].

Conveyor dapat ditemukan dalam berbagai jenis keadaan di suatu industri. Conveyor digunakan untuk memindahkan material atau hasil produksi dalam jumlah besar dari suatu tempat ke tempat lain. Conveyor mungkin memiliki panjang beberapa kilometer atau mungkin beberapa meter tergantung jenis aplikasi yang diinginkan

\section{METODOLOGI PENELITIAN}

Penelitian ini dilakukan melalui tiga tahapan yaitu: (1) Tahap perancangan atau design conveyor pada mesin planer kayu; (2) Tahap pembuatan conveyor mesin planer kayu berdasarkan spesifikasi dan dimensi yang telah ditentukan; (3) Tahap pengujian conveyor yang berorientasikan pada hasil capaian yang diharapkan, serta pengujian pada mesin planer kayu yang telah dilakukan proses perancangan dan pembuatan.

Tahap satu yaitu proses perancangan design conveyor, dilakukan kegiatan sebagai berikut: proses design yang meliputi design bentuk dan masing - masing komponen conveyor. Serta pemilihan material bahan yang akan digunakan. Tahap dua yaitu proses pembuatan conveyor yang terdiri atas komponen roller, meja conveyor. Proses pemesinan yang idgunakan dalam pembuatan conveyor ini meliputi pemotongan, pengeboran, pengelasan, dan pebubutan. Tahap ketiga yaitu pengujian conveyor yang berorientasikan hasil dari putaran conveyor sebesar $30 \mathrm{rpm}$. Berikut pada gambar 1, merupakan design perencanaan conveyor pada meisn planer. 


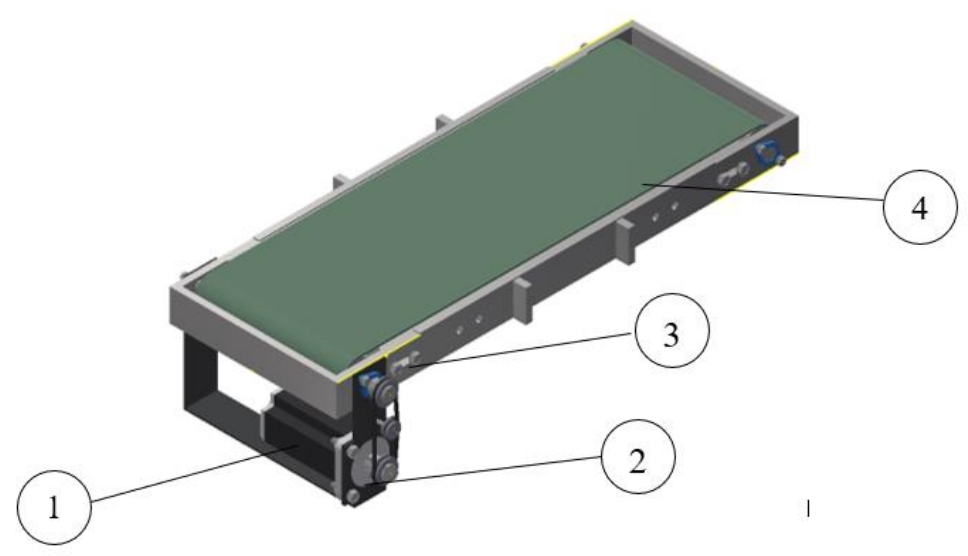

Keterangan gambar

Gambar 1. Conveyor

1. Dudukan motor stepper

2. Gear sprocket penggerak

3. Penyetel belt

4. Belt conveyor

Sistem kerja dari conveyor pada mesin planer ini pada umumnya adalah sebagai berikut:

1. Bahan atau material yaitu kayu diletakan pada conveyor bagia depan, selanjutnya bahan akan terbawa oleh conveyor ke cutter block.

2. Setelah material sampai tengah - tengah conveyor, material akan terproses oleh cutter block sesuai yang telah diinput pada sisitem control meja.

3. Selanjutnya material yang sudah terproses di cutter block akan tercurahkan diujung conveyor.

\section{HASIL DAN PEMBAHASAN}

Pada proses perencanaan conveyor pada mesin planer ini meliputi, perhitungan design, perhitungan pembuatan dan proses pengujian.

\subsection{Perhitungan perancangan conveyor}

Perhitungan proses perancangan yang dilakukan pada penelitian rancang bangun conveyor mesin planer kayu ini meliputi :

\section{Perencanaan spesifikasi}

Perhitungan dalam perancangan spesifikasi didasarkan pada rumus 1-2 dengan hasil pada tabel 1 sebagai berikut:

Perhitungan kapasitas berdasarkan persamaan 1:

$$
Q u=\frac{\text { panjang conveyor }}{\text { panjang kayu }}
$$

Perhitungan kapasitas beban maksimal berdasarkan persamaan 2:

$Q b=Q u \times M k$

Dengan $\mathrm{Qb}$ adalah kapasitas beban maksimal, Qu adalah kapasitas unit dan Mk adalah masa kayu

\section{Tabel 1 Spesifikasi}


Jurnal CRANKSHAFT, Vol. 2 No.1. Maret 2019

ISSN: 2623-0720 (Print), 2623-0755 (Online)

\begin{tabular}{lll}
\hline Bagian & Jenis Komponen & Hasil \\
\hline Kapasitas & Material (kayu) & $1 \mathrm{Unit}$ \\
& Beban Maksimal & $11,52 \mathrm{Kg}$ \\
\hline
\end{tabular}

\subsection{Perancangan komponen conveyor}

Perhitungan dalam perancangan komponen conveyor didasarkan pada beberapa persamaan dengan hasil pada tabel 2 berikut:

Tabel 2 Komponen Conveyor

\begin{tabular}{lll}
\hline Bagian & Jenis Komponen & Hasil \\
\hline Roller & Diameter $=50 \mathrm{~mm}$ \\
Komponen Conveyor & Pelt & Putaran $=30 \mathrm{rpm}$ \\
& Panjang $=1450 \mathrm{~mm}$ \\
& Lebar $=240 \mathrm{~mm}$ \\
& $\begin{array}{l}\text { Motor Stepper (NEMA 34) 2 } \\
\text { phase / 4 wires / 1.8 deg }\end{array}$ \\
\hline
\end{tabular}

\subsubsection{Roller conveyor}

Perhitungan perancangan roller didasrkan pada rumus berikut:

Perhitungan putaran roller[7] sebagaimana persamaan 3;

$$
n=\frac{v}{\pi \cdot D}
$$

Dengan $\mathrm{n}$ adalah putaran roller, $\mathrm{v}$ adalah kecepatan linier dan $\mathrm{D}$ adalah diameter roller Perhitungan torsi roller sebagaimana persamaan 4:

$$
T=i . \alpha
$$

Dengan $\mathrm{T}$ adalah torsi roller, $\mathrm{i}$ adalah inersia roller dan $\alpha$ adalah sudut putar

\subsubsection{Belt conveyor}

Perhitungan perancangan belt didasrakn pada rumus sebagai berikut:

Perhitungan panjang belt [8] sebagaimana persamaan 5;

$L=\pi\left(r_{1}+r^{2}\right)+2 \cdot x+\left(\frac{r 1-r 2}{x}\right)$

Dengan $\mathrm{L}$ adalah panjang belt, $\mathrm{r}_{1}$ adalah jari-jari roller $_{1}, \mathrm{r}_{2}$ adalah jari-jari roller ${ }_{2} \mathrm{dan} \mathrm{x}$ adalah jarak poros roller $_{1}$ ke poros $_{2}$

Perhitungan torsi belt sebagaimana persamaan 6:

$\mathrm{Tb}=\mathrm{F} . \mathrm{r}$

Dengan $\mathrm{F}$ adalah gaya dan $\mathrm{r}$ adalah jari-jari

\subsubsection{Daya motor}

Perhitungan perancangan daya motor didasarkan pada persamaan 7 berikut:

$$
P=\frac{2 \pi n}{60} \cdot T
$$

Dengan $\mathrm{P}$ adalah daya motor, $\mathrm{n}$ jumlah putaran dan $\mathrm{T}$ adalah torsi 
Berdasarkan data hasil perhitungan roller, belt conveyor dan daya motor maka dapat disimpulkan data perhitungan sebagaimana tabel 3 berikut:

Tabel 3 Data hasil perhitungan

\begin{tabular}{cc}
\hline Jenis komponen & Hasil \\
\hline Putaran roller & $30 \mathrm{Rpm}$ \\
Torsi roller & $9,9 \mathrm{Nm}$ \\
Panjang belt & $1450 \mathrm{~mm} \times 240 \mathrm{~mm}$ \\
Torsi belt & $23,17 \mathrm{Nm}$ \\
Daya motor & $0,14 \mathrm{~kW}$ \\
\hline
\end{tabular}

\subsection{Proses Pengujian}

Hasil dari proses pengujian conveyor mesin planer kayu dapat dilihat pada tabel 4 berikut ini:

Tabel 4. Hasil pengujian conveyor mesin planer

\begin{tabular}{|c|c|c|c|}
\hline Pengujian & Rpm & $\begin{array}{l}\text { Kecepatan } \\
(\mathrm{m} / \mathrm{s})\end{array}$ & Keterangan \\
\hline 1 & 30 & 0,059 & Tanpa beban \\
\hline 2 & 30 & 0,040 & $\begin{array}{c}\text { Beban 4,37 Kg } \\
\text { Dimensi } 600 \mathrm{~mm} \text { x } 100 \mathrm{~mm} \text { x } 40 \mathrm{~mm}\end{array}$ \\
\hline 3 & 30 & 0,034 & $\begin{array}{c}\text { Beban }{ }^{\wedge} \mathrm{Kg} \\
\text { Dimensi } 800 \mathrm{~mm} \times 200 \mathrm{~mm} \times 60 \mathrm{~mm}\end{array}$ \\
\hline
\end{tabular}

Hasil Pengujian menunjukkan dengan penambahan beban kecepatan konveyor mengalami penurunan.

\section{KESIMPULAN}

Dari rancang bangun conveyor mesin planer kayu dengan menggunakan motor stepper dapat disimpulkan sebagai berikut:

1. Design conveyor mesin planner kayu menggunakan belt conveyor tipe roughtop karena sesuai dengan material yang akan diangkut yaitu kayu dengan ukuran belt $1450 \mathrm{~mm}$ x 240 $\mathrm{mm}$.

2. Cara kerja conveyor ini cukup sederhana, yaitu membawa material (kayu) dari ujung conveyor menuju ke cutter block untuk proses penyerutan, setelah itu material akan sampai keujung conveyor.

3. Dari hasil pengujian conveyor tanpa beban dan dengan beban maka kecepatan conveyor akan berbeda tergantung beban material diatas belt.

\section{DAFTAR PUSTAKA}

[1] R. Raharjo, "Rancang Bangun Belt Conveyor Trainner Sebagai alat Bantu Pembelajaran," vol. 1, pp. 31-39, 2012.

[2] M. Asdar, "Sifat Pemesinan Kayu Surian ( Toona sinensis ( Adr . Juss .) M . J . Roemer ) dan Kepayang ( Pangium edule Reinw )," Penelit. Has. Hutan, vol. 28, no. 1, pp. 18-28, 2010.

[3] R. Setiawan, Rancang Bangun Mesin serut Otomatis Dengan Penggerak Motor LIstrik. 2014.

[4] Syahrul, "Motor Stepper: teknologi, metoda dan rangkaian kontrol," vol. 6, no. 2, pp. 187-202, 2013.

[5] S. F. Siregar, "Alat Transportasi Benda Padat,” pp. 1-11, 2004. 
[6] A. Rofeq, M. Kabib, Analisa Tegangan Screw Konveyor Pada Mesin Pencampur Garam dan Iodium Sesuai SNI 3556 dengan Metode Elemen Hingga, Jurnal Simetris volume 2 issue 2 2018, pp 935-940.

[7] R. S. Khurmi and J. K. Gupta, "A Textbook of Machine Design."

[8] S. Huda, M. Kabib, and R. Winarso, "Desain automatic line plastic packing of cake berbasis mikrokontroler atmega 328,"Seminar SNATIF 2017, pp. 577-584, 2017. 